Vol. 23, No. 1, pp. 38 53, 2020.

\title{
Sensing of ultra-low magnetic field by magnetoelectric (ME) composites
}

\author{
Geon-Tae Hwang $^{1 \dagger}$, Hyunseok Song ${ }^{1,2}$, Jongmoon Jang ${ }^{1}$, Jungho Ryu ${ }^{2}$, Woon-Ha Yoon ${ }^{1}$ \\ ${ }^{1}$ Korea Institute of Materials Science, Changwon 51508, Korea \\ ${ }^{2}$ Yeungnam University, Gyeongsan 38541, Korea
}

\section{자기-전기(ME) 복합체를 활용한 초미세 자기장 감지 기술}

\author{
황건태 $^{1 \dagger}$, 송현석 ${ }^{1,2}$, 장종문 ${ }^{1}$, 류정호 ${ }^{2}$, 윤운하 ${ }^{1}$ \\ ${ }^{1}$ 재료연구소, ${ }^{2}$ 영남대
}

(Received Febrary 24, 2020; Accepted March 17, 2020)

\begin{abstract}
초록
Magnetoelectric (ME) composites composed of magnetostrictive and piezoelectric materials derive interfacial coupling of magnetoelectric conversion between magnetic and electric properties, thus enabling to detect ultra-low magnetic field. To improve the performance of ME composite sensors, various research teams have explored adopting highly efficient magnetostrictive and piezoelectric phases, tailoring of device geometry/ structure, and developing signal process technique. As a result, latest ME composites have achieved not only outstanding ME conversion coefficient but also sensing of ultra-low magnetic field below $1 \mathrm{pT}$. This article reviews the recent research trend of ME composites for sensing of ultra-low magnetic field.
\end{abstract}

Keywords: magnetoelectric composite, magnetic field sensor, magnetostrictive material, piezoelectric material

\section{1. 서론}

지난 수십 년간 미세 자기장 감지에 대한 다양한 연구 가 진행되었으며, 기술적으로 엄청난 발전이 이루어졌
다. 과거 미세 자기신호 검출기술의 대부분은 전자기 효 과에 기초하고 있었으며 다양한 원리를 이용한 자기센 서가 제안되었다. 자기장 감지기로 널리 쓰이던 코일센 서(coil sensor)는 적의 잠수함 및 전차를 탐지하기 위

${ }^{\dagger}$ Corresponding Author: Geon-Tae Hwang

E-mail: gthwang@kims.re.kr 
(a)

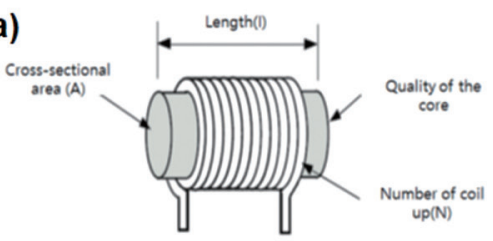

(b)

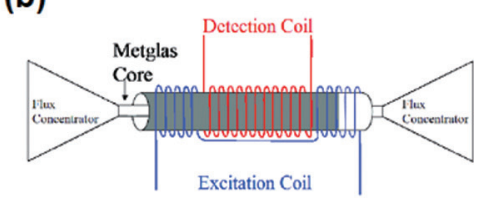

(c)

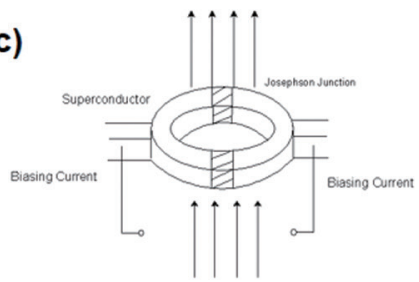

Fig. 1. 자기장 감지용 코일센서(a), 플럭스게이트(b), SQUID(c)의 기본구조

해 군사용으로 이용되던 장거리 탐지용 서치코일(search coil)을 응용 개발한 것으로 교류자기장 감지 특성이 뛰 어나며, 자기장 검출 민감도(sensitivity)도 매우 우수 하다. 코일센서의 기본원리는 패러데이 전자기 유도법 칙으로, 외부 자기장에 의해 유도된 전압은 코일을 통 과하는 자속의 변화율에 비례한다. 하지만 초미세 자기 장을 인식하기 위해서는 코일의 회전수와 반경이 증가 되어 부피와 무게가 증가하는 단점이 있다. ${ }^{1)}$ 플럭스게 이트(Fluxgate)센서는 코어에 충분한 크기의 교류자기 장을 인가하여 코어의 자화를 포화시킨 후, 측정할 외 부자기장이 코어에 인가될 때 포화자화에 도달하는 시 간이 비대칭으로 변화하게 되는데, 이 시간 차이에 의 한 자속의 변화를 이용하여 자기장의 크기를 감지한다. 플럭스게이트는 직류자기장 감지에 특화되어 있는데 감 지 할 수 있는 최소 자기장이 0.1nT로 비교적 좋지 못하 고 큰 전력을 소모하는 단점이 있다. ${ }^{2)}$ 초전도 양자간섭 장치(superconducting quantum interference device; $\mathrm{SQUID})$ 는 현존하는 최고의 감도를 나타내는 자기장 감 지장치이며 조셉슨(Josephson)효과를 기반으로 동작한 다. 일반적으로 SQUID에 의해 측정가능한 자기장의 크 기는 $0.1 \mathrm{fT}$ 수준이고, 오랜 시간동안 평균을 측정할 경우 더욱더 작은 크기의 자기장 감지가 가능하다. 그러나 초 전도체의 냉각을 위해 액체헬륨이 이용되기에 전체 장비 의 부피가 크고 구입 및 유지하는데 많은 비용이 든다. ${ }^{3)}$

초미세 자기장 감지센서는 다양한 분야에서 응용이 가능하지만 파급이 가장 큰 분야 중 하나는 생체자기 (biomagnetism)의 측정이다. 살아있는 생명체는 생명 유지를 위하여 세포막을 통해 $\mathrm{Na}^{+}, \mathrm{K}^{+}, \mathrm{Ca}^{2+}, \mathrm{Cl}^{-}$등 여 러 종류의 이온들을 끓임없이 교환한다. 이러한 극성을
띤 이온들의 이동은 아주 미세한 전류를 만들어내고 암 페어(Ampère)의 법칙에 의해 교류자기장을 발생시키는 데, 이처럼 생물이 자체적으로 만들어내는 자기신호를 생체자기라 한다. 생체자기의 측정은 약 100년전부터 이루어졌는데, 심전도(electrocardiogram, ECG) 및 심 장근육으로부터 발생하는 신호(magnetocardiogram, $\mathrm{MCG}$ )를 측정하기 위해 구리코일을 이용하였지만 잡 음 때문에 정확한 측정에 한계가 있었다. 생체자기 의 정확한 측정은 앞서 언급한 SQUID의 등장으로 가 능하게 되었다. 그림 2 는 인체에서 발생하는 자기 장과 주변에서 흔히 존재하는 자기장 노이즈, 자기 장 측정센서의 감도를 보여주고 있다. ${ }^{3)}$ 생체자기장 은 심장 외에도 뇌(magnetoencephalogram, MEG), 근육(magnetomyogram, $\mathrm{MMG}$ ), 눈(magnetooculogram, MOG) 등에도 존재하는데, 그 크기가 매우 미세하고 발생 주파수가 $0.01 \sim 1000 \mathrm{~Hz}$ 로 비교적 낮기 때문에 SQUID외에는 감지가 어렵다. 인체의 미세 자기 장 발생은 부위에 따라 뇌신경세포, 심장근육세포, 척 수신경세포 등에서 이루어지며, 세포집단의 부피에 의 해 자기장의 세기가 정해지므로 척수에서는 약 $10 \mathrm{fT}$, 뇌 에서는 약 $100 \mathrm{fT}$, 심장에서는 약 $10 \mathrm{pT}$ 수준의 자기장이 발생한다. 이는 지구에서 발생하는 자기장의 크기 $(50 \mu$ T)와 비교해 보았을 때 매우 작은 수준임을 알 수 있다. 이러한 인체 생체자기장 분석을 통해 심장질환 및 뇌기 능 이상을 진단할 수 있으며, 뇌기능을 측정하면 인지융 합에 관한 연구가 가능하다. SQUID가 현재까지 인체자 기장을 성공적으로 측정하는 장치로 이용되고 있지만, 높은 장치비용 및 극저온 냉각이 요구되는 단점이 존재 하기 때문에 새로운 기술을 활용한 초미세 자기장 센서 


\section{특 집 ㄸㅃ 황건태, 송현석, 장종문, 류정호, 윤운하}

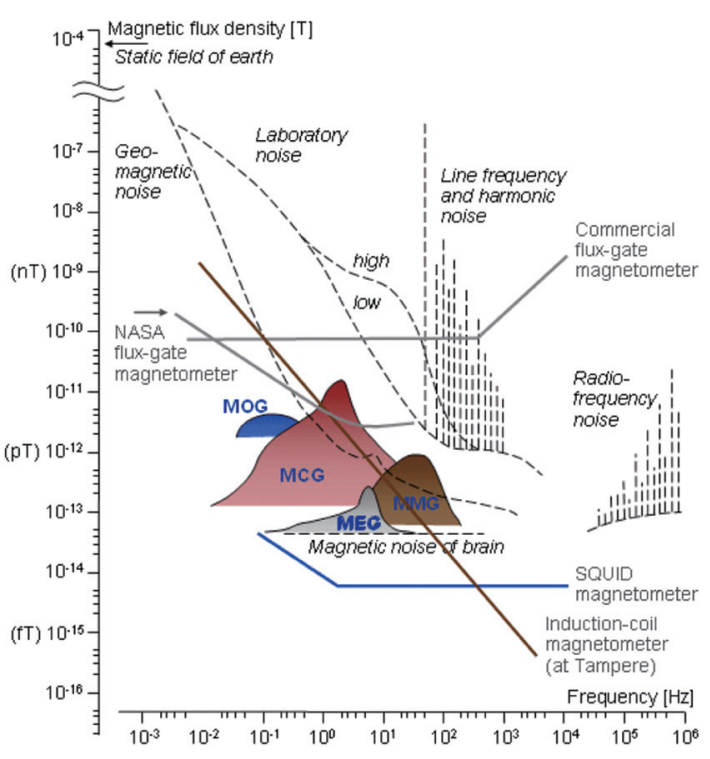

Fig. 2. 인체에서 발생하는 생체자기신호의 크기 및 각종 자기장 센서의 감도

구현에 관한 연구가 필요하다.

압전체와 자왜소재를 결합하여 복합화한 자기-전기 (Magnetoelectric, ME) 복합체는 상기한 SQUID의 단 점을 가지지 않으면서 작은 부피, 저비용 구현, 고민감 도의 장점을 가지고 있다. 본고에서는 $\mathrm{ME}$ 복합체를 활 용하여 초미세 자기장 감지 기술에 대하여 국내외 연구 동향과 발전 가능성에 대해 소개 하고자 한다.

\section{2. 자기-전기(ME) 복합체}

자기-전기(magnetoelectric, $\mathrm{ME}$ )효과는 어떠한 물 질이 자기장과 전기장에 반응하는 특성을 동시에 가지 고 있어 자기장에 노출되었을 때는 전기적으로 전압이 발생하고, 반대로 전기장에 노출되었을 때는 자기적 성 질이 변화하는 특성을 보여준다. ${ }^{4)}$ 주요 응용분야로는 고민감도의 자기장 센서 및 자기장을 전기에너지로 변 환하는 에너지 하베스터 등이 있다. ${ }^{5)}$ 약 60 년전 최초로 발견된 $\mathrm{ME}$ 효과를 발생하는 물질은 $\mathrm{Cr}_{2} \mathrm{O}_{3}$ 등의 단일상 재료였는데, 강자성과 강유전성이 동시에 나타내기 위 해 두 특성의 큐리(Curie)온도 이하에서만 구현이 가능 했기에 상온에서의 응용이 불가능하였다. 또한 극저온
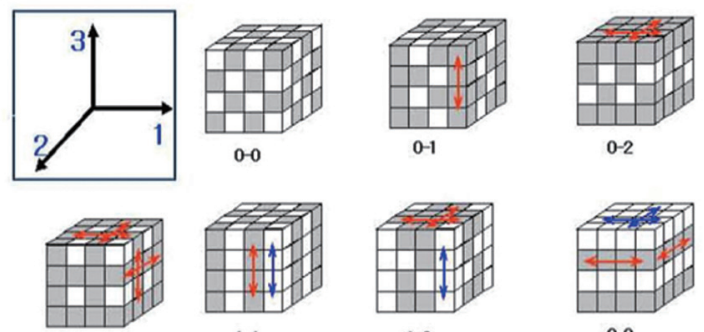

1-1
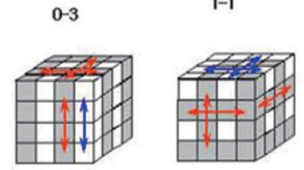

2-3

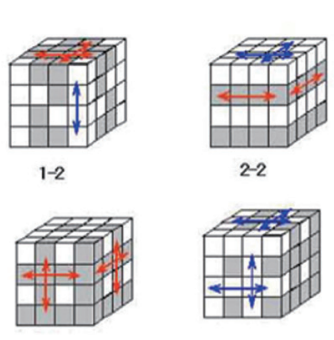

3-3(Two Views)

Fig. 3. 다양한 복합체의 결합구조

에서 구현되는 $\mathrm{ME}$ 변환특성 또한 매우 미약하여 실용 화하기 어려운 측면이 있었다. ${ }^{6}$ 이러한 단점을 극복하 기 위해 자기장에 반응하는 자성물질과 전기장에 반응 하는 강유전 물질을 복합화 하여 상온에서 높은 $\mathrm{ME}$ 변 환특성을 보이고자 하는 연구가 활발히 이루어져 왔다. $\mathrm{ME}$ 복합체는 1970 년대 강유전체인 $\mathrm{BaTiO}_{3}$ 와 자성체인 Ferrite를 복합화하는 연구로 시작되었으며 90년대 말 까지 다양한 복합체에 대해 연구되었다. 하지만 이 역 시 $\mathrm{ME}$ 변환특성이 미약하여 에너지 하베스터 및 고감도 자기장 센서로 사용하기에는 한계가 있었다. 2000년대 초에는 물질에 입자를 섞은 복합체의 한계를 극복하기 위해 압전재료-자왜재료 층상복합체(2-2 결합구조)에 대한 연구가 시작되었다. ${ }^{7}$ 이로부터 다양한 재료를 활용 하여 층상복합체가 제작되었고, 재료물성 및 구조의 최 적화가 이루어졌다. 복합체는 형상에 따라 그림3과 같이 두 물질의 결합형태 및 연결도에 따라 10 종의 구조로 나 누어지고 고성능의 $\mathrm{ME}$ 복합체 구현에는 주로 $2-2$, 및 1-1 등의 형태가 사용된다. ${ }^{8)}$

압전소재 및 자왜소재의 물리적 복합체에서 $\mathrm{ME}$ 변환 특성이 구현되는 원리는 그림4에 나타나 있다. $\mathrm{ME}$ 복 합체는 압전체와 자왜재료가 접착층에 의해 물리적으로 부착되어 있는데, 외부에서 자기장이 인가된 경우 자왜 재료는 물질고유 특성(자왜효과)으로 인해 기계적인 변 형을 일으킨다. 이 변형의 크기는 인가된 자기장에 비례 


\section{Magnetoelectric (ME) Composite}

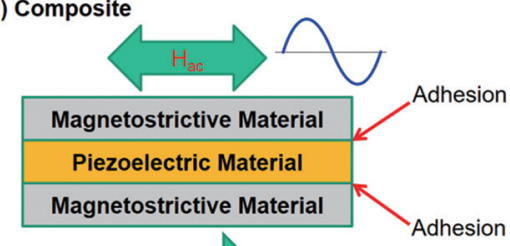

Bias Field

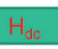

Magentoelectric (ME) Coupling Coefficient $(\mathrm{V} / \mathrm{cm} \cdot \mathrm{Oe})$

$$
\alpha_{M E}=k \underbrace{\frac{\partial \varepsilon}{\partial H}\left(\frac{\partial E}{\partial \varepsilon}\right)^{\text {Piezoelectric }}}_{\text {Magnetostrictive }}
$$

Fig. 4. $\mathrm{ME}$ 복합체의 작동원리 및 $\mathrm{ME}$ 결합계수의 구성

하여 증가하는데 이 크기를 자왜상수(magnetostrictive coefficient; $\mathrm{d} \varepsilon / \mathrm{dH}$ )로 나타낼 수 있다. 압전체는 자왜 재료와 물리적으로 결합되어 있으므로 자왜재료에서 발 생한 변형을 전달받으면 압전효과로 인해 전기적인 전 압을 생성하는데, 이 크기는 압전상수(piezoelectric coefficient; $\mathrm{dE} / \mathrm{d} \varepsilon$ )에 의해 재료 변형의 크기에 비례 한다. 이는 자왜효과에 의한 자기장에너지-기계에너지 변환 및 압전효과에 의한 기계에너지-전기에너지 변환 의 2 단계에 걸친 에너지 변환과정으로 이를 모두 통합 하여 자기-기계-전기(magneto-mechano-electric, $\mathrm{MME})$ 변환으로도 명명한다. 이러한 $\mathrm{ME}$ 변환특성은 자 왜효과와 압전효과가 결합하여 나타나기 때문에 우수한 특성을 얻기 위해서는 고효율의 자왜재료 및 압전재료 를 사용해야 하고, 두 재료간의 계면결합특성 $(\mathrm{k})$ 이 최적 화되어 자왜재료에서 발생한 응력이 압전재료에 효과적 으로 전달되어야 한다. 이렇게 자왜특성, 압전특성, 계 면결합특성 $(\mathrm{k})$ 을 조합하면 $\mathrm{ME}$ 결합계수( $\mathrm{ME}$ coupling coefficient; $\alpha_{\mathrm{ME}}$, 단위: $\mathrm{V} / \mathrm{cm} \cdot \mathrm{Oe}$ )로 나타낼 수 있는 데, 이는 결과적으로 $\mathrm{ME}$ 복합체에 인가된 자기장에 대 해 발생하는 전압의 크기를 의미한다. ${ }^{9}$

$\mathrm{ME}$ 층상복합체의 $\mathrm{ME}$ 결합상수를 향상시키기 위 해 우수한 특성의 자왜금속 및 압전세라믹 $\mathrm{Pb}(\mathrm{Zr}, \mathrm{Ti})$ $\mathrm{O}_{3}(\mathrm{PZT})$, 압전단결정 등이 이용되었고, 이종재료간의 강한 물리적 결합 및 낮은 상호확산 가능성으로 인해
$100 \mathrm{~Hz}$ 미만의 저주파에서도 수 $\mathrm{V} / \mathrm{cm} \cdot \mathrm{Oe}$ 의 높은 $\mathrm{ME}$ 결합계수가 발생하고 있으며, 전기/자기/기계적 공진주 파수 에서는 수백 수천 $\mathrm{V} / \mathrm{cm} \cdot \mathrm{Oe}$ 의 매우 높은 $\mathrm{ME}$ 결 합계수를 얻을 수 있다. 이러한 특성을 이용하면 미세한 자기장을 감지하는 초소형/저전력의 자기센서 제작이 가능하다.

\section{3. 자기-전기(ME) 복합체를 이용한 자기셴서 연구동향}

모든 종류의 $\mathrm{ME}$ 복합체는 자기장 감지를 위한 자기센 서로 사용될 수 있다. 다양한 방법을 이용해 $\mathrm{ME}$ 복합체 의 성능을 극대화 시키면 초미세 자기장을 감지할 수 있 고, 더 나아가 생체에서 발생하는 자기장 등을 감지하는 데 이용될 수 있을 것이다. 외부에서 특정 주파수를 가 진 교류자기장이 발생되면 이는 $\mathrm{ME}$ 복합체의 구성요소 인 자왜소재에 동일한 주파수의 진동을 유발시키고, 자 왜소재에서 발생된 교류진동은 압전소재에 교류응력으 로 전달된다. 이후 압전체에 전달된 기계적인 응력은 정 압전 효과에 의해 기전력 발생으로 이어져 이를 신호로 측정하면 외부 자기장의 변화를 감지할 수 있다.

일반적으로 교류자기장은 고유의 주파수를 가지고 있 는데, 이를 효율적으로 측정하기 위해서는 $\mathrm{ME}$ 복합체 의 공진주파수를 측정하고자 하는 교류자기장의 주파 수에 일치시키는 것이 유리하다. 이는 앞서 언급하였듯 이 $\mathrm{ME}$ 복합체의 결합계수가 비공진과 공진 주파수에 서 비교했을 때 수십 수백배 차이나는 특성에서 기인한 다. 이 때문에 $\mathrm{ME}$ 복합체의 공진주파수 조절이 중요하 며, 실제 응용처가 존재하는 미세자기장의 주파수 범위 는 $1 \mathrm{kHz}$ 미만으로 비교적 낮은 편이므로 자왜/압전체의 물성 및 소자의 구조설계를 통한 $\mathrm{ME}$ 복합체의 공진주파 수를 $1 \mathrm{kHz}$ 미만으로 유지하는 것이 실용화에 유리하다. 현재까지 $\mathrm{ME}$ 복합체를 이용한 자기장 센서의 공진 주파 수는 수십 $\mathrm{Hz} \sim$ 수십 $\mathrm{kHz}$ 범위로 제작되고 있으며, 다양 한 연구를 통해 $\mathrm{ME}$ 결합계수 향상 및 감지가능한 자기 장의 크기를 낮추려는 시도가 진행되고 있다. 본고에서 는 $\mathrm{ME}$ 복합체를 활용한 자기장 감지 연구동향에 대해 소개하고자 한다. 
Table 1. 세라믹 PZT와 단결정 PMN-PT의 주요물성 비교

\begin{tabular}{lccc}
\hline \hline & $d_{33, p}(\mathrm{pC} / \mathrm{N})$ & $g_{33, p}(\mathrm{mV} \mathrm{m} / \mathrm{N})$ & $k_{33}$ \\
\hline PZT $^{\mathrm{a}}$ & 440 & 25.5 & 0.72 \\
PMN-PT $^{\mathrm{b}}$ & 2000 & 32.4 & 0.93 \\
\hline \hline
\end{tabular}

${ }^{a}$ Cited from Smart Material Corp., USA.

${ }^{\mathrm{b}}$ Cited from Ceracomp Co., Ltd., Korea.

\subsection{2-1결합 ME 복합체를 이용한 고민감도 자기센서}

일반적으로 $\mathrm{ME}$ 복합체는 층상의 2-2 결합(가로방향 의 자화 및 세로방향 분극 or 가로방향의 자화 및 가로 방향의 분극)이 많이 이용되었는데, 2006년 중국 칭화 대 연구진은 2-1 결합의 자왜 FeBSi(Metglas) 및 압전 세라믹 $\mathrm{PZT}$ 복합체를 이용하여 비공진 $\mathrm{ME}$ 변환계수를 $22 \mathrm{~V} / \mathrm{cm}$ - Oe까지 향상시켰다. ${ }^{10)}$ 이후 2011년 미국 버 지니아공대에서는 2-1 결합의 Metglas 및 압전단결정 $\mathrm{Pb}\left(\mathrm{Mb}_{1 / 3} \mathrm{Nb}_{2 / 3}\right) \mathrm{O}_{3}-\mathrm{PbTiO}_{3}(\mathrm{PMN}-\mathrm{PT})$ 복합체를 활용하 여 $\mathrm{ME}$ 변환계수를 높이며 미세 자기장 감지를 시도 하 였다. ${ }^{11)} \mathrm{PZT}$ 세라믹에 비해 PMN-PT 단결정은 압전상 수 $\mathrm{d}_{33}$ 기준으로 약 3 배 이상 높은 값을 가지고 있는데, 이는 압전체에 동일한 변형이 가해졌을 때 압전상수 차 이만큼 많은 전하가 발생함을 의미하고 발생되는 압전 기전력이 클 가능성이 높음을 의미한다. 또한 전기기계 결합계수 $\left(\mathrm{k}_{33}\right)$ 는 압전체의 기계에너지-전기에너지 변환 효율을 의미하는데, 기존 $\mathrm{PZT}\left(\mathrm{k}_{33}=0.5\right)$ 에 비해 압전 단 결정은 우수한 $\left(\mathrm{k}_{33}=0.9\right)$ 값을 가지기 때문에 전기에너 지 생성에 유리하다. 본 연구에서는 압전 세라믹과 압 전 단결정을 이용하여 $\mathrm{ME}$ 복합체를 제작하고 두 압전 물질간 $\mathrm{ME}$ 변환특성 및 자기장 감지성능에 대해 비교 분석 하였다. 두 압전체의 주요 물성인 압전 전하상수 $\left(\mathrm{d}_{33}\right)$, 압전 전압상수 $\left(\mathrm{g}_{33}\right)$, 전기기계 결합계수 $\left(\mathrm{k}_{33}\right)$ 는 표1 에 나타나 있다. 앞서 언급했든 세라믹에 비해 단결정은 주요물성이 우수하여 높은 $\mathrm{ME}$ 결합계수 및 자기장 감 지 감도를 가질 수 있다. $\mathrm{ME}$ 소자의 제작을 위해 깍지 형태(Interdigitated)전극이 코팅된 Polyamide가 $180 \mu$ $\mathrm{m}$ 두께의 압전체의 아래위에 부착되어 패키징을 이루었 고, 자왜금속인 Metglas가 압전체 패키징 아래위에 부 착되어 샌드위치 형태를 만들었다. $\mathrm{ME}$ 소자의 비공진
$\mathrm{ME}$ 결합계수 특성을 보기위해 $\mathrm{PZT}$ 세라믹 및 $\mathrm{PMN}-$ $\mathrm{PT}$ 단결정 복합체에 $1 \mathrm{Oe}, 1 \mathrm{kHz}$ 의 교류자기장을 인가한 상태에서, 추가로 인가하는 직류자기장의 크기를 변화 시켰고 $\mathrm{ME}$ 복합체에서 출력되는 전압을 측정하여 그림 5 (a)와 같은 결과를 얻었는데 단결정 $\mathrm{PMN}-\mathrm{PT}$ 에서는 $45 \mathrm{~V} / \mathrm{cm} \cdot \mathrm{Oe}, \mathrm{PZT}$ 세라믹에서는 $15 \mathrm{~V} / \mathrm{cm} \cdot \mathrm{Oe}$ 의 $\mathrm{ME}$ 결합계수가 출력되었다. 공진주파수에서 $\mathrm{ME}$ 결합계수 를 측정하기 위해 그림5 (b)와 같이 교류자기장의 주파 수의 크기를 바꾸어가며 전압을 측정하였고, 그 결과 단 결정에서는 약 $1100 \mathrm{~V} / \mathrm{cm} \cdot \mathrm{Oe}$, 세라믹에서는 약 $350 \mathrm{~V} /$ $\mathrm{cm} \cdot \mathrm{Oe}$ 이 출력되었다. 이후 $\mathrm{ME}$ 복합체의 자기장 감지 성능을 평가하였는데, 소자에 $0.10 \mathrm{e}, 10 \mathrm{kHz}$ 의 교류자 기장을 인가한 상태에서 감지가능한 최소의 직류자기장 을 측정하였다. 그 결과 그림5 (c), (d)와 같이 PZT 세라 믹은 $12 \mathrm{nT}, \mathrm{PMN}-\mathrm{PT}$ 단결정은 $4 \mathrm{nT}$ 를 감지하였다. 이 처럼 압전단결정은 고유의 우수한 물성으로 인해 월등한 $\mathrm{ME}$ 결합상수 및 자기장 감지특성을 보여주었다. 이러 한 직류자기장 센서는 지자기장의 변화를 감지하여 위 치를 파악하는 네비게이션으로 사용될 수 있고 이론적 으로는 $50 \mathrm{~m}$ 의 정밀도로 위치변화 탐지가 가능하다.

\subsection{ME 복합체의 주파수 변환을 통한 자기장 민감도 향상}

$\mathrm{ME}$ 복합체를 이용한 자기장 센서는 내/외부 노이즈 로 인해 낮은 주파수에서 민감도가 좋지 못한 한계가 있 는데, 이는 구동 주파수를 변환할 수 있는 $\mathrm{ME}$ 복합체를 이용하면 해결할 수 있다. 2013년 중국 상해세라믹대에 서는 주파수 변환을 이용해 $\mathrm{ME}$ 센서의 동작 주파수를 이동하여 민감도를 낮추는 연구를 진행하였다. ${ }^{12)} \mathrm{ME}$ 센 서의 자기장 민감도를 측정하기 위해 Metglas와 PMNPT로 그림6 (a)와 같은 형태의 $\mathrm{ME}$ 복합체를 제작하였 다. 주파수에 따른 $\mathrm{ME}$ 결합계수를 측정하여 $22 \mathrm{kHz}$ 에 서 공진 주파수를 확인하였고, $1 \mathrm{kHz}$ 부터 $22 \mathrm{kHz}$ 까지 의 반송파 주파수 $(1,7,13,19 \mathrm{~Hz})$ 에서 측파대의 노이즈 를 비교하였다. 여기서 주파수가 증가할수록 측파대의 노이즈가 증가하는 경향을 나타내었다. 이런 측파대 노 이즈의 증가현상을 설명하기 위해 반송파 주파수 부근 
(a)

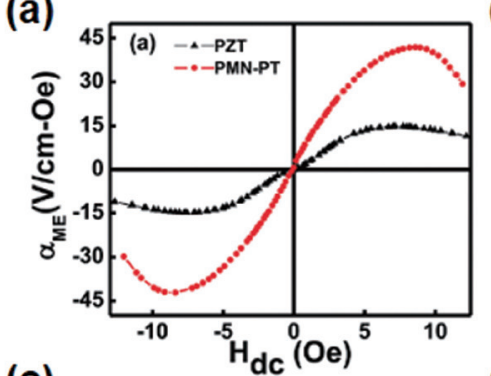

(c)

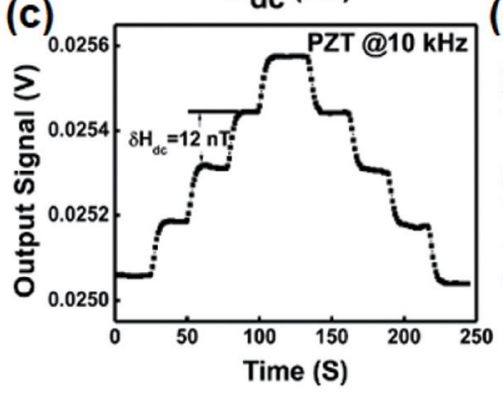

(b)
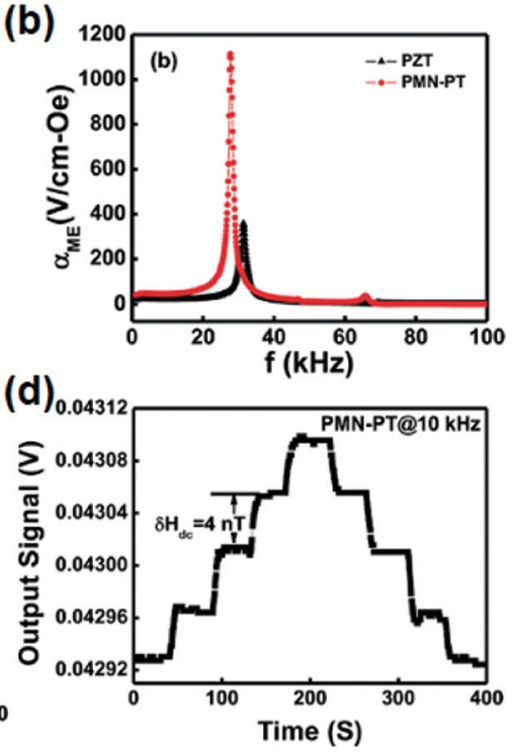

Fig. 5. (a)비공진 주파수 분위기에서 측정한 세라믹 PZT 및 단결정 PMN-PT 기반 ME 복합체의 ME 결합상수, (b)세라믹 PZT 및 단결정 PMN-PT ME 복합체의 주파수 변환에 따른 ME 결합상수, (c)세라믹 PZT 기반 ME 복합체의 자기장 감지특성, (d)단결정 PMN-PT 기반 $\mathrm{ME}$ 복합체의 자기장 감지특성
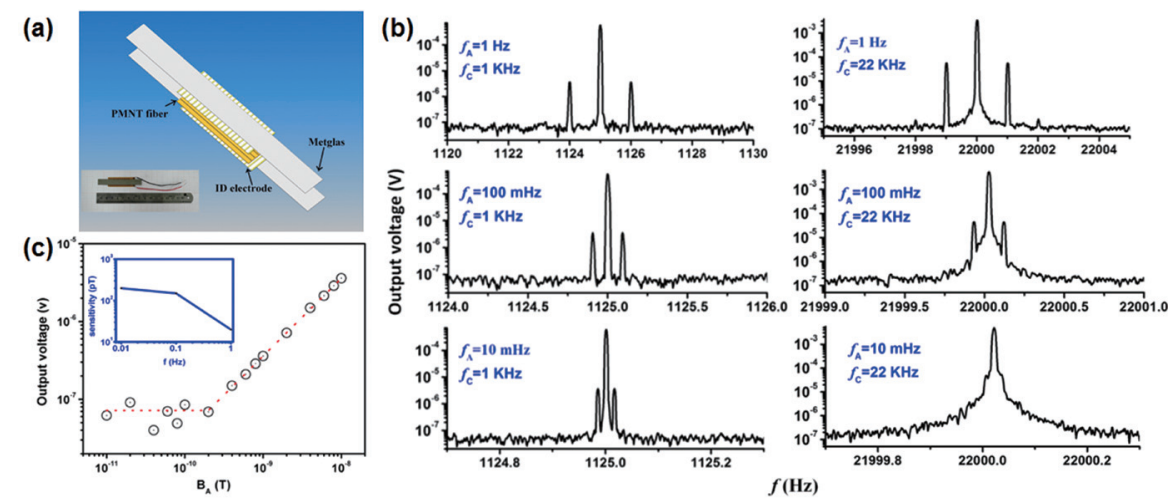

Fig. 6. (a)동작 주파수 변환을 이용한 자기장 감지 민감도를 측정하기 위한 ME 복합체의 구조, (b)동작 주파수 최적화를 위한 입사 주파수 별 자기장 감지, (c)제작된 ME 자기장 센서의 민감도

의 전체 노이즈와 구동전류로 인한 노이즈를 비교하였 다. 반송파 주파수에서 멀어질수록 전체 노이즈의 구동 전류로 인한 노이즈 차이가 크지만, 반송파 주파수 주변 의 전체 노이즈와 구동전류로 인한 노이즈 차이는 거의 없었다. 이를 근거로 연구팀은 측파대 노이즈는 구동전 류로 인한 것으로 밝혔다. 또한 반송파 주파수를 최적화 하기 위해 그림6 (b)에서와 같이 $1 \mathrm{kHz}, 22 \mathrm{kHz}$ 의 반송
파 자기장에서 $\mathrm{ME}$ 복합체를 구동하여 $1 \mathrm{~Hz}, 100 \mathrm{mHz}$, $10 \mathrm{mHz}$ 의 입사 자기장을 감지하였다. 그 결과, $1 \mathrm{~Hz}$ 의 감지에서는 신호 대 잡음비가 $22 \mathrm{kHz}$ 의 반송파 주파수 에서 높았고 $100 \mathrm{mHz}, 10 \mathrm{mHz}$ 의 감지에서는 신호 대 잡 음비가 $1 \mathrm{kHz}$ 의 반송파 주파수에서 높은 값을 가졌다. 그림6 (c)에서와 같이 구동 주파수를 변환하는 $\mathrm{ME}$ 자 기장 센서는 $10 \mathrm{mHz}, 100 \mathrm{mHz}, 1 \mathrm{~Hz}$ 에서 자기장 민감도 

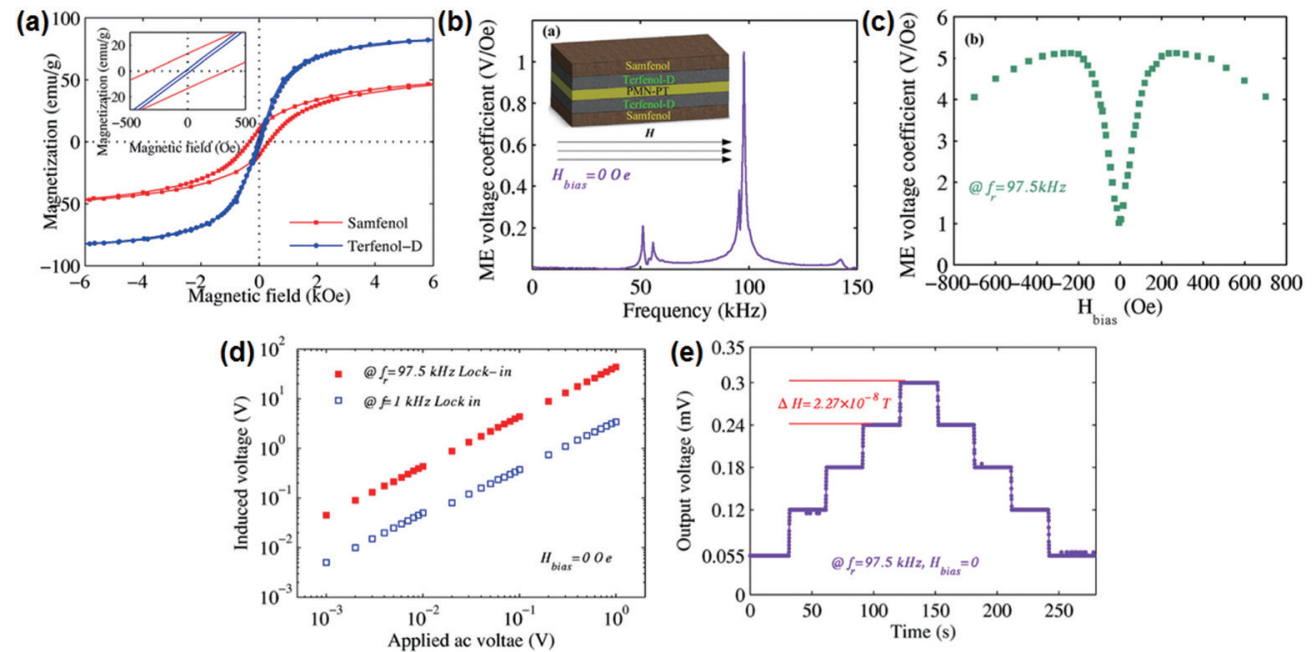

Fig. 7. (a)SmFe $\mathrm{S}_{2}$ 와 Terfenol-D의 자기적 특성 비교, (b)ME 복합체의 주파수에 따른 ME 결합계수, (c)공진에서의 바이어스 자기장에 따른 $\mathrm{ME}$ 결합계수, (d)ME 자기센서의 공진주파수와 저주파수에서의 자기감지 특성, (e)외부 바이어스가 없을 때의 자기장 감지 민감도

각각 $200 \mathrm{pT}, 150 \mathrm{pT}, 20 \mathrm{pT}$ 를 나타냄으로서 기존 저주 파 $\mathrm{ME}$ 자기장 센서에 비해 10 배 이상 우수한 민감도를 가진다. 이처럼 본 연구의 $\mathrm{ME}$ 자기장 센서는 동작 주 파수 변환을 통해 내/외부적 노이즈를 최소화함으로서 $0.1 \mathrm{~Hz}$ 이하 주파수의 자기장을 감지하는데 장점을 가지 고 있다.

\section{3 양/음의 자왜재료 이용한 고민감도 ME 복합체 자기감지 센서}

기존에는 $\mathrm{ME}$ 자기센서의 민감도를 높이기 위해 외 부 바이어스(직류) 자기장을 이용해 $\mathrm{ME}$ 효율을 증가시 켰다. 하지만 이러한 방법은 장치의 부피를 증가시키게 되는데, 이를 개선하기 위해 2014년 중국 충칭대 연구 팀은 양의 자왜재료인 Terfenol-D와 음의 자왜재료인 $\mathrm{SmFe}_{2}$, 압전 $\mathrm{PMN}-\mathrm{PT}$ 를 이용한 $\mathrm{ME}$ 복합체를 제작하 여 외부 바이어스 자기장이 없는 $\mathrm{ME}$ 자기센서로 응용 하는 연구를 진행하였다. ${ }^{13)}$ 바이어스 자기장이 없이 자 기센서를 구동하기 위해서는 두 가지 요소가 작용한다. 첫 째로 $\mathrm{SmFe}_{2}$ 의 비등방적 내부 자기장으로 인해 자기 바이어스 자기장이 증가하게 된다. 그림7 (a)에서처럼 $\mathrm{SmFe}_{2}$ 의 히스테리시스와 잔류자화가 더 강하게 나타 나는데, 이는 내부 비등방상수 $\left(\mathrm{K}_{1}=-5.3 \times 10^{6} \mathrm{ergs} / \mathrm{cm}^{3}\right)$
가 크기 때문이다. 따라서 내부 자기장이 비등방성을 갖 고 자기 바이어스 자기장을 증가시키게 되는 것이다. 또 한 자왜 방향이 다른 두 자왜재료를 결합함으로서 바이 어스 교환 자기장을 발생시켜 자체 바이어스를 증가시 킬 수 있다. 이러한 원리를 바탕으로 그림7 (b) 제작된 $\mathrm{ME}$ 복합체의 공진 주파수를 찾기 위해 바이어스 자기 장 없이 $\mathrm{ME}$ 결합계수를 측정하였을 때, $97.5 \mathrm{~Hz}$ 의 공진 주파수에서 $1.1 \mathrm{~V} / \mathrm{Oe}$ 의 $\mathrm{ME}$ 계수를 가졌다. 공진 주파수 $97.5 \mathrm{~Hz}$ 에서 바이어스 자기장에 따른 $\mathrm{ME}$ 를 측정한 그 림7 (c)에서처럼 자체 바이어스 자기장에서의 $\mathrm{ME}$ 계수 값은 최댓값 $4.5 \mathrm{~V} / \mathrm{Oe}$ 에 비교했을 때 상대적으로 작은 값이지만 자기센서의 자석을 제거함으로서 부피를 줄일 수 있다는데 의의를 둔다. 바이어스 자기장이 없을 때, $\mathrm{ME}$ 자기센서의 민감도를 나타낸 그림7 (d)를 보면 센 서에서 발생된 전압이 입력전압과 비례하여 선형적으로 증가하는 것을 볼 수 있는데, 민감도는 공진에서와 반공 진에서 각각 $1.1 \mathrm{~V} / \mathrm{Oe}, 8.7 \mathrm{mV} / \mathrm{Oe}$ 의 값을 가진다. 결과 적으로 자체적인 바이어스 자기장으로 구동된 소형 $\mathrm{ME}$ 자기감지 센서는 $22.7 \mathrm{nT}$ 의 작은 자기장 변화를 감지하 는데 성공하였다. 연구팀이 개발한 자체 바이어스 $\mathrm{ME}$ 자기센서는 외부 바이어스의 의존성을 줄임으로서 센서 의 부피는 줄일 수 있게 되었지만, 여전히 외부 바이어 
(a)

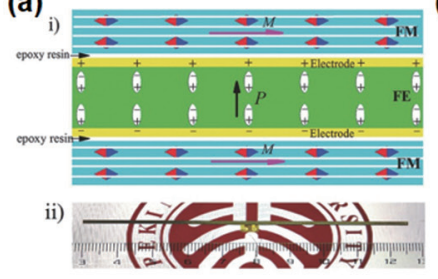

(d)

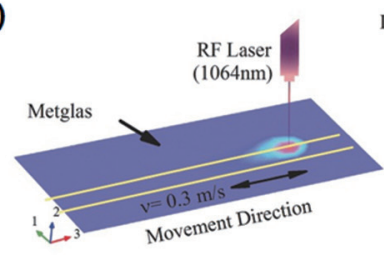

(f)

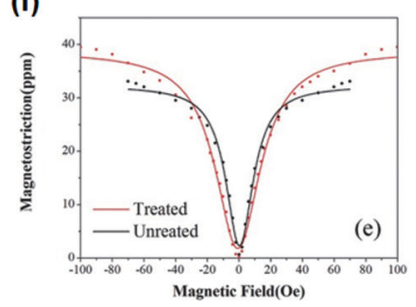

(b)

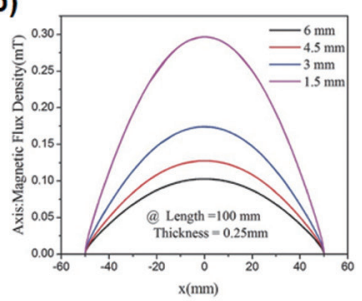

Untreated

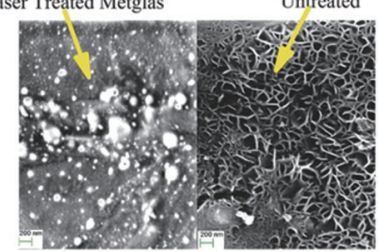

(g)

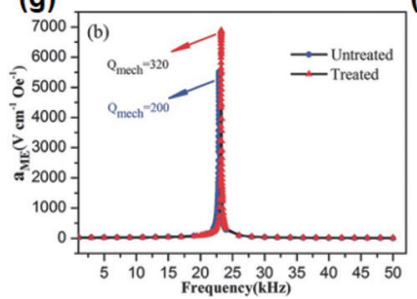

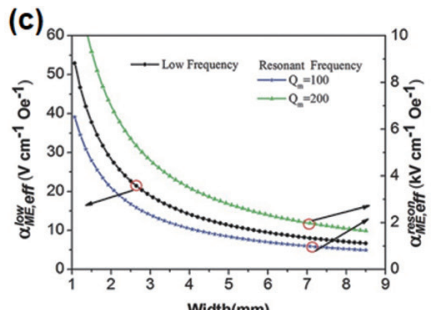

(e)

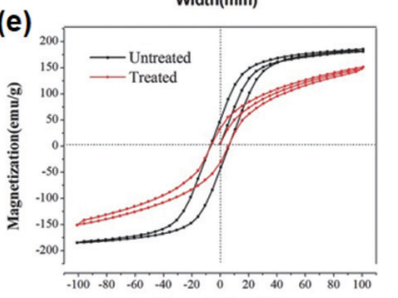

Magnetic field(Oe)

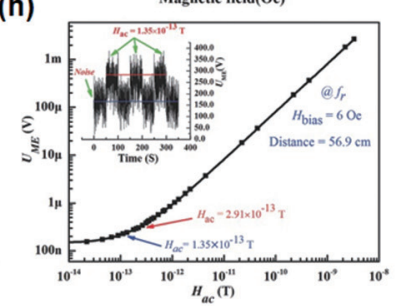

Fig. 8. (a)1-1 결합 ME 복합체의 모습, (b)종횡비에 따른 Metglas의 자기선속밀도 시뮬레이션 결과, (c)종횡비에 따른 ME 복합체의 ME 결 합계수 시뮬레이션 결과, (d) 레이저를 이용한 Metglas 열처리 모식도 및 SEM 이미지, (e)레이저 열처리 전/후 Metglas의 자화특성, (f)레이저 열처리 전/후 Metglas의 자왜특성, (g)레이저 열처리 전/후 ME 복합체의 주파수 별 결합계수, (h) ME 복합체를 활용한 초 미세 교류자기장 감지특성

스를 이용한 센서의 민감도에는 미치지 못한 것으로 보 인다.

\subsection{1-1결합 ME 복합체를 이용한 초고민감도 자기센서}

$\mathrm{ME}$ 복합체의 성능을 향상시키기 위해 다양한 방법이 사용될 수 있는데, $\mathrm{ME}$ 복합체의 형태 최적화 및 자왜금 속의 물성개선으로도 목표를 달성할 수 있다. 2017년 중 국 북경대에서는 1-1 결합구조의 $\mathrm{ME}$ 복합체를 제작하였 고, 자왜 Metglas의 기계적 품질계수를 향상시키기 위 해 레이저 열처리를 시도하였다. ${ }^{14)} 1-1$ 결합은 종횡비 (너비/길이)를 극도로 낮추어 $\mathrm{ME}$ 복합체를 1차원의 얇 고 길쭉한 모양으로 제작하는 것을 의미한다. 연구팀은 그림8 (a)처럼 1-1 결합의 자왜 Metglas, 압전 단결정 $\mathrm{PMN}-\mathrm{PT} \mathrm{ME}$ 복합체를 제작하였다. 이렇게 1-1 결합
을 이용하면 자왜재료의 자기소거(demagnetization)값 이 최소화되어 소자내부에 큰 자기선속밀도(magnetic flux density)를 유발할 수 있다. 이는 그림8 (b)에서 보 여주는 것처럼 시뮬레이션 계산을 통해 확인하였는데, 소자의 길이는 고정시키고 너비의 크기를 줄일수록 자 왜재료에서 발생하는 자기선속밀도의 크기가 점점 증 가하는 것을 알 수 있다. 이러한 종횡비의 감소는 그림 8 (c)의 시뮬레이션 결과처럼 $\mathrm{ME}$ 결합계수의 증가로 도 이어질 수 있다. 한편 소자의 기계적 품질계수 $\left(\mathrm{Q}_{\mathrm{m}}\right)$ 가 클수록 $\mathrm{ME}$ 변환성능이 우수한 것으로 알려져 있는데, 여기서 $\mathrm{Q}_{\mathrm{m}}$ 은 기계적 진동흡수(damping) 때문에 나타 난 응력에 대한 변위의 집중도로 정의되고, 이 값이 클 수록 진동시에 기계적 에너지 손실이 작음을 의미한다. 본 연구에서는 Metglas에 레이저 열처리를 통해 자왜 재료의 $\mathrm{Q}_{\mathrm{m}}$ 을 향상시키는 연구도 진행하였다. 연구팀은 
파장 $1064 \mathrm{~nm}$ 의 라디오주파수 $(\mathrm{RF})$ 레이저를 이용하여 Metglas의 표면을 열처리 하였는데, 레이저는 비정질상 인 Metglas 표면에서 핵생성 및 부분 결정화를 유발하 여 철산화물(ferric oxide) 나노결정을 형성한다. 이러 한 과정은 Metglas 표면의 잔류응력에 영향을 주고 보 다 취성의(brittle) 성질을 유발하며, 재료의 $\mathrm{Q}_{m}$ 을 향상 시킨다. 그림8 (d)에는 레이저 스캔을 이용한 Metglas 표면 열처리 공정 및 레이저 조사 전/후의 표면 주사전 자현미경 $(\mathrm{SEM})$ 사진이 나타나 있는데, 레이저 열처리 후에 표면에 국부적인 용융 및 응고로 인한 나노결정립 이 관찰되었다. 레이저 열처리를 진행한 Metglas는 그 림8 (e) 및 (f)처럼 자화특성 및 자왜특성에도 변화를 유 발하는데, 잔류/포화자화의 감소 및 자왜 최대변형율의 상승이 주요한 특성변화로 나타났다. 이후 $\mathrm{ME}$ 복합체 를 제작하였는데 공진주파수에서 열처리 전 샘플은 $\mathrm{ME}$ 결합상수 및 $\mathrm{Q}_{\mathrm{m}}$ 은 $5600 \mathrm{~V} / \mathrm{cm}$ · Oe 및 200인데 반해 레 이저 열처리 후에는 $7000 \mathrm{~V} / \mathrm{cm} \cdot \mathrm{Oe}$ 및 320 까지 향상 되었다. 또한 열처리를 진행한 $\mathrm{ME}$ 복합체의 교류자기 장 감지특성을 측정해봤는데, $23 \mathrm{kHz}$ 의 주파수에서 최 소 $0.14 \mathrm{pT}$ 의 초미세 교류자기장을 감지하는데 성공하였 다. 본 논문에서 달성한 $\mathrm{ME}$ 변환상수 및 교류자기장 감 지특성은 현재까지 보고된 최고의 특성이지만, 레이저 의 열처리 공정에 많은 시간이 소모되고 $23 \mathrm{kHz}$ 의 동작 주파수는 실제 응용하기에는 너무 높아 적절한 응용분 야를 찾기 어려운 단점이 있다.

\section{5 압전단결정 ME 복합체를 활용한 저주파 자기신호 감지}

현재까지 발표된 $\mathrm{ME}$ 복합체 자기장 센서는 $1 \mathrm{kHz}$ 미 만의 저주파 영역이 아닌 대부분 수십 $\mathrm{kHz}$ 대역의 고주 파에서 동작하기 때문에 실제 응용에는 무리가 있다. 2017년 재료연구소에서는 $500 \mathrm{~Hz}$ 미만의 미세자기장 을 감지하는 $\mathrm{ME}$ 복합체 자기센서를 개발하였다. ${ }^{15)}$ 실 험에 사용된 자왜재료는 니켈이고, 압전재료는 단결정 $\mathrm{Pb}\left(\mathrm{Mg}_{1 / 3} \mathrm{Nb}_{2 / 3}\right) \mathrm{O}_{3}-\mathrm{PbZrO}_{3}-\mathrm{PbTiO}_{3}(\mathrm{PMN}-\mathrm{PZT})$ 로 $\mathrm{ME}$ 복합체의 자기장 감지 민감도를 측정하기 위해 그 림9 (a)와 같은 시스템을 구축하였다. 외부 자기장 노이
즈를 제거하기 위해 자기장 차폐박스를 제작하였고, 헬 름홀츠 코일에 교류전류를 인가하여 미세한 교류자기장 을 발생하였을 때 $\mathrm{ME}$ 복합체에서 생성되는 전압을 측 정하였다. 이번 연구에서는 다양한 $\mathrm{Q}_{\mathrm{m}}$ 값을 가지고 있는 압전 단결정을 사용하였는데, 기계적 손실에 따라 high, medium, low-loss라고 명명하였다. 세 가지 단결정의 주파수 변화에 따른 임피던스 분석을 실시해 보았는데, 약 $60 \mathrm{~Hz}$ 및 $500 \mathrm{~Hz}$ 에서 공진이 관찰되었으며 low-loss 단결정의 임피던스 값이 가장 큰 것을 알 수 있었다. 압 전 단결정의 임피던스가 크면 $\mathrm{ME}$ 복합체에서 자기장의 변화에 의해 발생할 수 있는 전압의 크기가 커져 자기장 센싱에 유리한 장점이 있다. $\mathrm{ME}$ 복합체의 응용가능 범 위를 파악하기 위해 자기장 감지 특성을 측정하였다. 측 정은 초기에 $\mathrm{ME}$ 복합체에 교류자기장 $25 \mu \mathrm{T}$ 를 인가하 였고, $50 \mathrm{pT}$ 씩 자기장의 크기를 줄여가며 측정이 가능한 최소 교류자기장의 크기를 찾는 방법으로 진행되었다. 그림9 (b)에서는 공진 주파수인 $500 \mathrm{~Hz}$ 의 교류자기장 에서 측정된 자기장 감지 결과를 보여주고 있다. high, medium, low-loss의 단결정 $\mathrm{ME}$ 복합체를 이용하였 을 때, low-loss 단결정 샘플에서 가장 낮은 범위의 교 류 자기장 측정이 되었으며 측정 한계 값은 $25 \mathrm{pT}$ 였다. 측정된 자기장 센싱 민감도는 기존의 상용 자기센서인 Hall effect, 플럭스게이트, 거대자기저항효과(GMR) 센 서보다 10 1000배 이상 향상된 우수한 결과이다. 추가 적으로 $\mathrm{ME}$ 복합체의 자기장 감지 성능을 확인하기 위해 low-loss 단결정 $\mathrm{ME}$ 복합체에 $2 \mathrm{nT}$ 의 폭으로 교류자기 장의 크기로 계단형태로 올렸다가 내렸을 때 그에 상응 하는 모양으로 전압이 출력되는지 확인해 보았다. 그 결 과 그림9 (c)에서처럼 교류자기장의 크기를 $2 \mathrm{nT}$ 씩 증가 시키고 감소 시켰을 때 뚜렷한 폭으로 $\mathrm{ME}$ 복합체의 출 력 전압이 증가 및 감소하였으며, 노이즈가 거의 없이 미세 자기장 감지능력이 있는 것을 확인하였다. 본 연구 를 통해 $500 \mathrm{~Hz}$ 미만의 저주파에서도 $100 \mathrm{pT}$ 이하의 교 류자기장 감지가 가능함을 확인했지만, 추후 생체자기 장 영역인 $1 \mathrm{pT}$ 이하의 교류자기장을 감지하기 위해 재 료의 물성, 구조 등의 개선이 필요하다. 
(a)

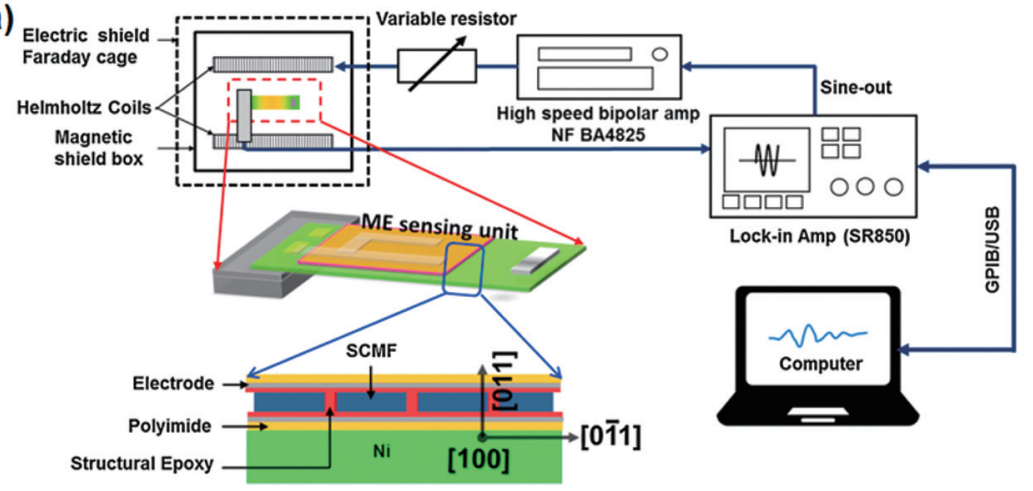

(b)

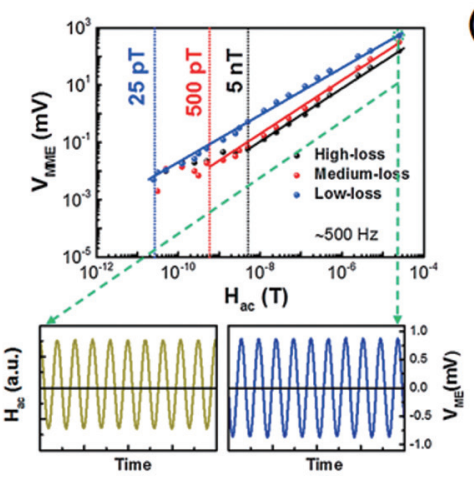

(c)

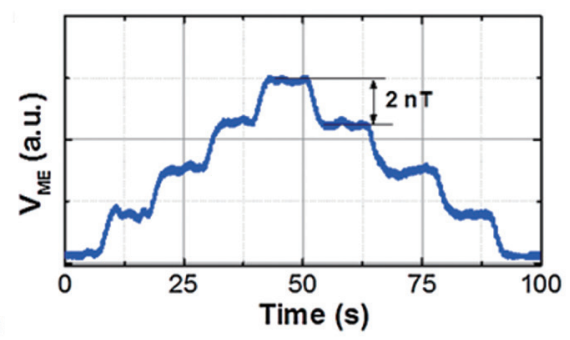

Fig. 9. (a)ME 복합체의 자기감지 민감도를 측정하기 위한 시스템의 구성도 및 ME 복합체의 구조, (b) $500 \mathrm{~Hz}$ 의 교류자기장에서 측정된 자기 감지 특성, (c)2nT의 크기로 교류자기장을 계단형태로 ME 복합체에 인가했을 때 출력전압의 모습

\subsection{ME 복합체의 접착제 최적화를 통한 자기장 감지성능 향상}

앞서 언급하였듯 $\mathrm{ME}$ 복합체의 성능을 결정하는 요소 에는 크게 압전재료와 자왜재료, 인터페이스의 접착층 이 있는데, 이 중 압전재료와 자왜재료의 특성을 개선하 여 $\mathrm{ME}$ 결합계수를 향상하고자 하는 시도는 많이 있었지 만 접착제 최적화를 통한 $\mathrm{ME}$ 복합체 성능개선에 관한 연구는 거의 이루어지지 않았다. 2018년 재료연구소에 서는 압전-자왜재료 인터페이스 접착층에서 $\mathrm{ME}$ 결합 계수에 영향을 미칠 수 있는 요소를 이론적으로 탐구하 고 접착층의 최적화를 진행하였다. 최종적으로는 초미 세 교류자기장 감지가 가능한 $\mathrm{ME}$ 복합체 센서를 개발하 였다. ${ }^{16)}$ 본 연구의 $\mathrm{ME}$ 복합체 제작에 사용된 자왜재료 와 압전재료는 Metglas와 PMN-PZT 단결정으로 그림 10 (a)처럼 여러 장의 Metglas호일을 접착제를 이용해 결합하고, 이를 접착제를 이용해 $\mathrm{PMN}-\mathrm{PZT}$ 와 샌드위
치 구조로 결합하였다. 시뮬레이션 툴을 이용하여 분석 해본 결과 $\mathrm{ME}$ 결합계수에 영향을 미치는 접착층의 주요 물리적 특성은 영률과 두께로 판단되었고, 그림10 (b)와 (c)의 시뮬레이션 결과에 나타난 것처럼 접착제의 영률 이 클수록, 접착층의 두께가 얇을수록 $\mathrm{ME}$ 결합계수는 상승하였다. 시뮬레이션 결과를 검증하기 위해 Metglas 와 $\mathrm{PMN}-\mathrm{PZT}$ 복합체 접착제의 영률과 두께를 변화 하 였을 때 주파수에 따른 $\mathrm{ME}$ 결합계수를 측정하였는데, 그림10 (d)와 (e)에서 나타난 것처럼 영률이 클수록, 두 께가 얇을수록 우수한 특성을 보여주었다. 접착제의 물 리적/기계적 성질에 따른 특성변화를 보다 심도있게 비 교하기 위해 $\mathrm{ME}$ 복합체를 교류자기장 감지가 가능한 센 서로 이용하였다. 접착층의 영률이 큰 접착제가 우수한 교류자기장 감지특성을 보여주었으며, $117 \mathrm{kHz}$ 에서 9.2 $\mathrm{pT}$ 의 초미세 자기장 감지에 성공하였다. 접착층의 두께 변화를 주었을 때는 얇을수록 교류자기장 감지 특성이 

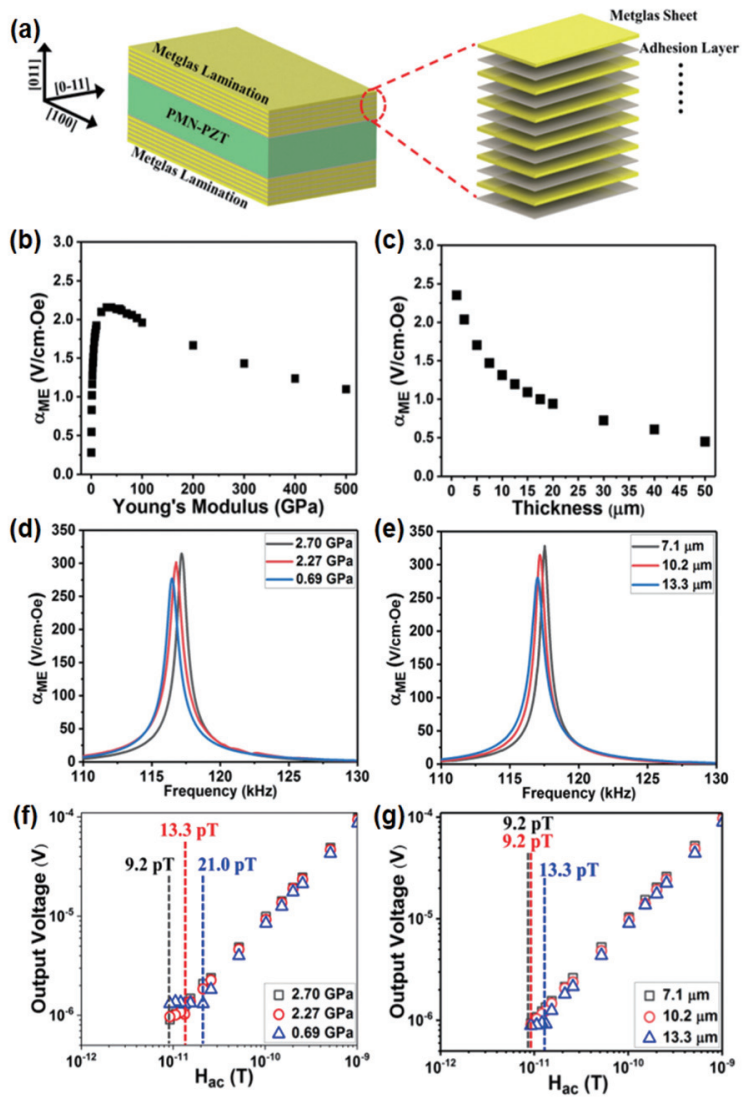

Fig. 10. (a)본 연구에 사용된 $\mathrm{ME}$ 복합체의 구조, $\mathrm{ME}$ 복합체 접착 층의 영률(b) 및 두께(c)가 $\mathrm{ME}$ 결합계수에 미치는 영향, (d)(e)인터페이스 접착층의 영률 및 평균두께 변화에 따른 $\mathrm{ME}$ 복합체의 ME 결합계수 특성, (f)(g)ME 복합체 접착층 의 영률 및 평균두께 변화에 따른 교류 자기장 감지특성 비교

우수하였으며, $117 \mathrm{kHz}$ 에서 마찬가지로 $9.2 \mathrm{pT}$ 의 자기 장 감지에 성공하였다. 본 연구에서는 $\mathrm{ME}$ 복합체에서 접착층의 물리적/기계적 특성이 $\mathrm{ME}$ 변환성능에 영향을 미치는 것을 확인하였고, 접착층의 물성개선 방향을 제 시하였다.

\subsection{ME 자기센서의 배열을 통한 자기스케치}

기존에 사용되던 다양한 자기센서에 비해 $\mathrm{ME}$ 복합체 는 우수한 민감도와 저비용, 작은부피, 쉬운 제조법 등 의 이점을 가진다. 하지만 미세 자기장 감지 외에 물체 의 위치를 추적하는 등 응용분야를 확장하려는 시도는
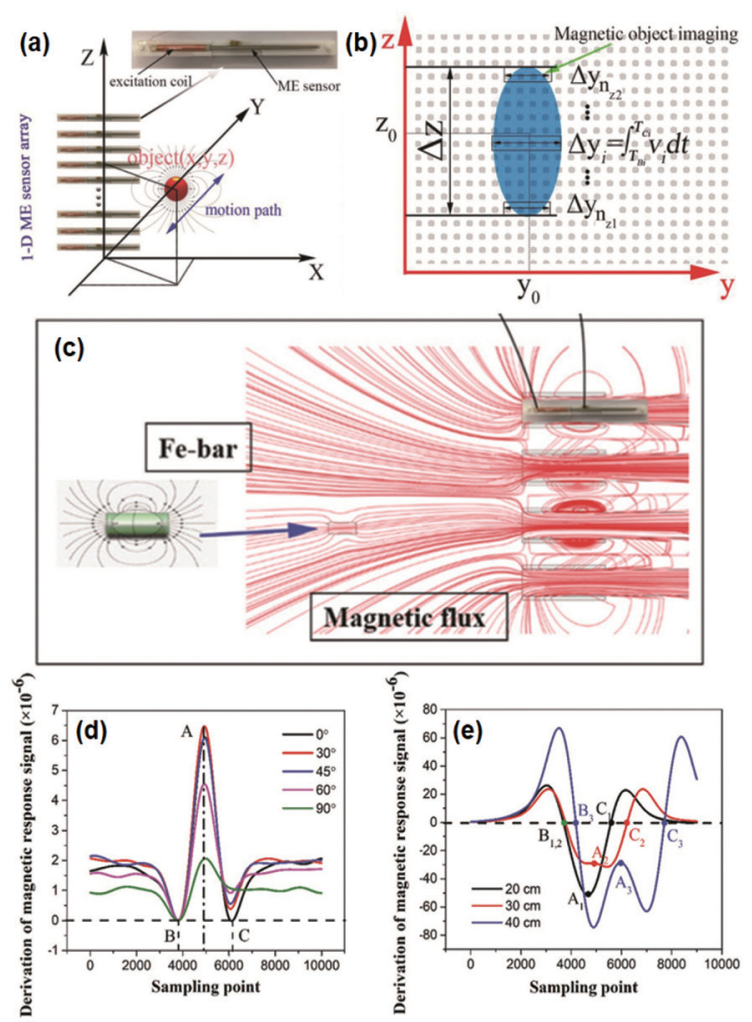

Fig. 11. ME 복합체의 배열을 통해 금속 구의 위치를 측정하기 위한 시스템(a)과 위치 계산 과정(b), 금속 막대의 방향과 종횡비 를 측정하기 위한 시스템(c), ME 자기센서 배열을 이용하 여 계산된 이동하는 금속 막대의 위치에 따른 방향(d)과 종 횡비(e)

이루어지지 않았다. 2018년 중국 북경대 연구팀은 1-1 구조의 $\mathrm{ME}$ 복합체 여러 개를 배열하여 움직이는 소형의 금속 물체의 위치와 각도, 종횡비 등을 감지하는데 성 공하였다. ${ }^{17)}$ 연구팀은 구형 철의 위치를 감지하기 위해 그림11 (a)과 같이 공진 주파수에서는 $5600 \mathrm{~V} / \mathrm{cm} \cdot \mathrm{Oe}$, $1 \mathrm{kHz}$ 에서는 $28 \mathrm{~V} / \mathrm{cm} \cdot \mathrm{Oe}$ 의 $\mathrm{ME}$ 변환계수를 갖는 $\mathrm{ME}$ 자기센서를 2 차원으로 배열하였다. 이 때, 근접한 3 개의 센서들은 각각 공진 주파수를 달리하여 자기감지에 있 어서 혼선을 없애고, 필터링 시간을 줄였다. 배열된 $\mathrm{ME}$ 자기센서의 금속물체 위치 감지를 위해 그림 11 (b)와 같 이 바이어스 자기장 속을 구형 철이 이동할 때, 배열된 각각의 $\mathrm{ME}$ 자기센서들이 감지하는 자기장 크기의 차이 로 인해 물체의 위치가 계산되었다. 또한 그림11 (c) 금 속막대의 방향과 종횡비를 감지하기 위한 시스템이다. 
(a)

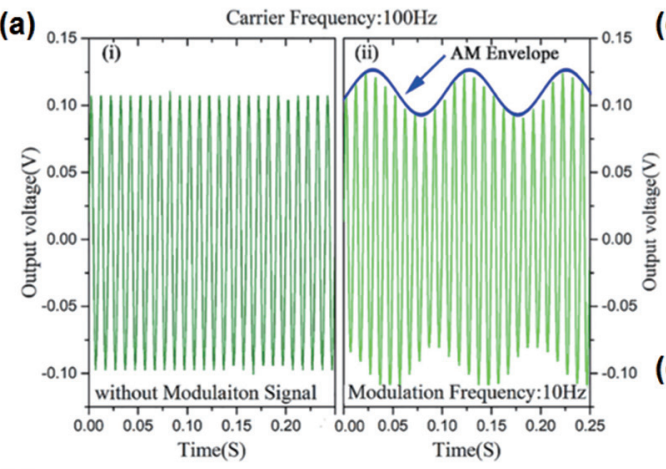

(b)

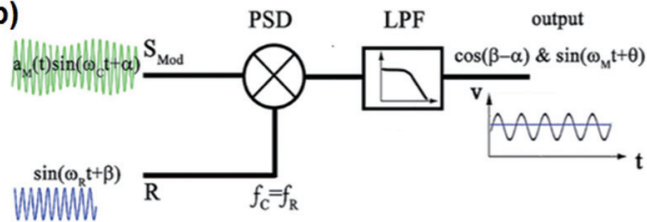

(c)

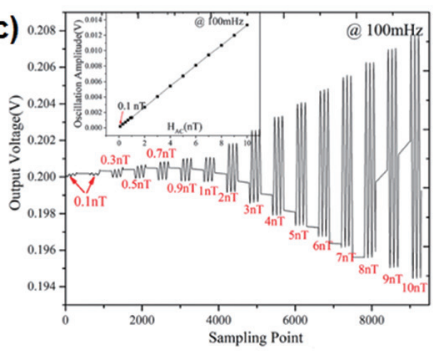

(d)

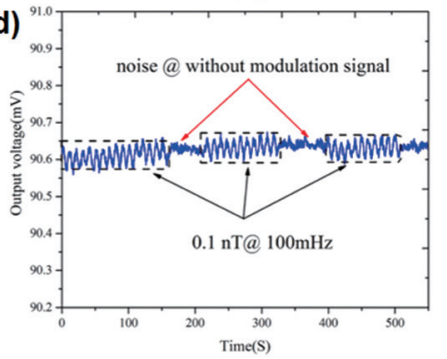

Fig. 12. (a)변조되지 않은 신호와 변조된 신호로 인해 발생된 ME 복합체의 출력신호, (b)변조신호와 참고신호의 상관 감지를 통해 노이즈를 제거하기 위한 구성, (c)변조신호를 이용한 ME 자기감지 센서의 신호에 따른 자기감지 특성 (d)노이즈와 0.1nT의 변조신호로 인한 출력 비교

먼저 교류전류가 흐르는 코일에서 자기장이 발생하고, 각각 다른 방향과 다른 종횡비를 가진 막대 형태의 금 속이 교류자기장 사이를 일정한 속도로 이동할 때 배열 된 $\mathrm{ME}$ 자기센서들에 감지된 자기장 크기의 차이로 인 해 금속막대의 방향과 종횡비를 파악하는 원리이다. 연 구팀이 사용한 금속막대는 일정한 속도로 이동하기 때 문에 감지된 자기장 신호는 금속막대의 이동한 변위 또 는 시간의 함수로 나타낼 수 있고, 그림11 (d), (e)와 같이 방향과 종횡비를 파악할 수 있다. 이 연구는 현재로서 는 이론적이고 예비적인 측면이 있지만, 생체자기 영역 과 보안 영역에 있어서의 응용을 기대할 수 있고, 기존 의 금속감지 또는 이미징 시스템이 갖는 비용과 민감도 의 한계를 극복하는 의의를 갖는다.

\section{8 진폭변조를 통한 저주파 ME 자기센서}

앞서 언급 하였듯, $\mathrm{ME}$ 자기센서는 저주파에서 노이즈 가 커 $1 \mathrm{~Hz}$ 이하의 교류자기장을 감지하는 데에 어려움 이 있었다. 이를 극복하기 위해 $\mathrm{ME}$ 복합체의 구동 주파 수 변환기술이 개발되었지만, 이 기술을 이용하면 $\mathrm{ME}$ 복합체의 출력이 감소되어 신호의 증폭과정이 필요하
다. 2019년 중국 북경대 연구팀에서는 변조된 자기장의 증폭을 이용해 주파수 변환기술이 적용된 센서의 출력 누출을 개선하는 연구를 진행하였다. ${ }^{18)}$ 본 연구에 사용 된 자기센서는 1-1 결합으로 이루어진 $\mathrm{ME}$ 복합체이다. 제작된 $\mathrm{ME}$ 자기센서는 $100 \mathrm{~Hz}$ 의 주파수로 $20 \mu \mathrm{T}$ 의 반 송파 자기장이 가해졌을 때 그림 $12(\mathrm{a}-\mathrm{i})$ 와 같이 $0.2 \mathrm{~V}_{\mathrm{pp}}$ 의 일정한 출력을 갖는다. 반면 $10 \mathrm{~Hz}$ 의 저주파수로 $1 \mu$ $\mathrm{T}$ 의 변조 자기장을 추가적으로 가해주면 그림12 (a-ii) 와 같이 증폭 변조된 출력을 나타낸다. 그림12 (b)는 증 폭 변조된 신호를 참고신호와의 상관감지를 통해 노이 즈를 제거하는 과정을 나타낸 모식도인데, 여기서 증폭 변조된 입력신호의 주파수와 참고신호의 주파수가 일 치할 때 불균일한 노이즈를 줄여 신호 대 잡음비를 높 여준다. 연구팀이 사용한 $\mathrm{ME}$ 복합체는 $20 \mu \mathrm{T}$ 의 참고신 호와 함께 $100 \mathrm{mHz}, 1 \mathrm{nT}$ 의 증폭 변조된 신호가 가해지 면 $1.2 \mathrm{mV}$ 의 출력을 갖는다. 그림12 (c)는 변조된 신호 에 따른 $\mathrm{ME}$ 복합체의 출력을 나타내었는데, 결론적으 로 $100 \mathrm{pT}$ 의 자기장을 감지하는 것을 알 수 있다. $100 \mathrm{pT}$ 자기장을 감지할 때 배경 노이즈의 영향을 확인하기 위 해 그림12 (d)와 같이 $100 \mathrm{mHz}$ 의 주파수에서 출력을 확 

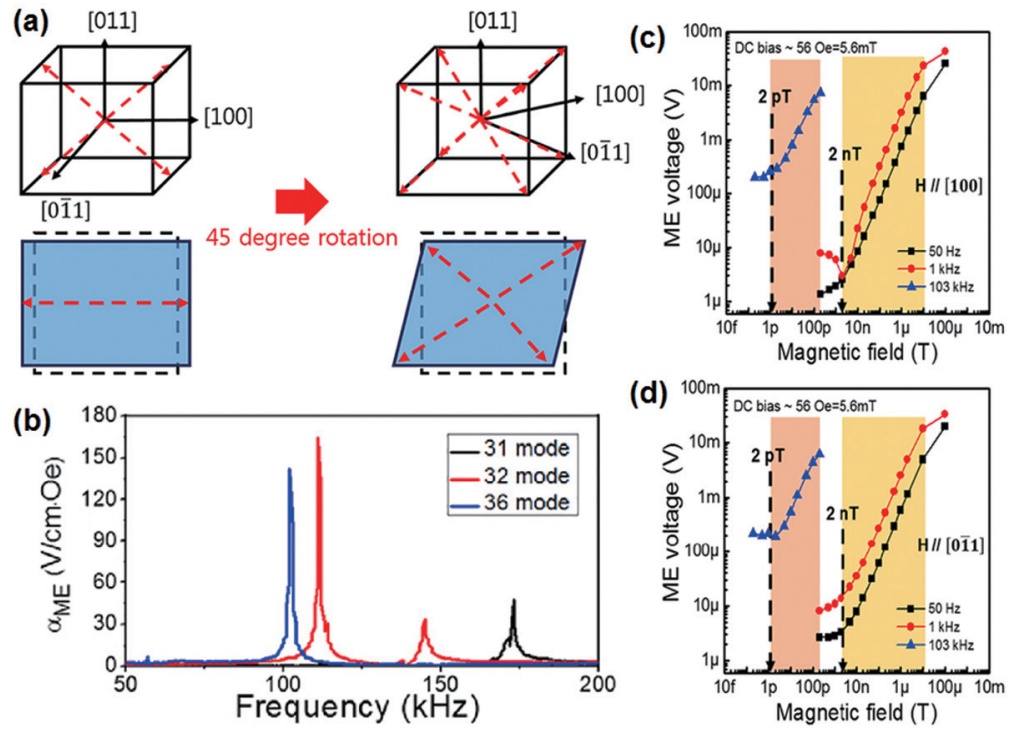

Fig. 13. (a) $d_{32}$ 모드와 $d_{36}$ 모드 단결정의 자발 분극 방향, (b) $d_{31}, d_{32}, d_{36}$ 모드 ME 복합체의 주파수에 따른 ME 계수 비교, (c)(d)입력 자기장 방 향과 동작 주파수에 따른 자기장 감지 특성비교

인하였다. 변조신호의 입력이 없는 경우 배경 노이즈와 비교했을 때 변조신호에 의해 유발된 출력 신호는 확연 히 구별될 수 있음을 밝혔다. $100 \mathrm{pT}$ 의 민감도는 이전의 주파수 변환 방식을 이용한 연구와 비교하여 크게 향상 된 결과이다. 본 연구에서 다룬 것처럼 $\mathrm{ME}$ 복합체에서 출력되는 신호를 다양한 방법으로 처리하면 성능을 올 릴 수 있는 여지가 있기에, 앞으로 관련 연구가 많이 이 루어질 것으로 예상된다.

\section{9 압전 $\mathrm{d}_{36}$ 모드 $\mathrm{ME}$ 복합체를 이용한 자기센서}

압전모드는 압전체 내부에 정렬된 분극의 방향과 물 리적 변형이 일어나는 방향의 관계에 의해 결정된다. 일 반적인 세라믹 압전소자에서는 분극의 방향과 변형의 방향이 같은 $\mathrm{d}_{33}$ 모드 및 분극의 방향과 변형의 방향이 수 직인 $\mathrm{d}_{31}$ 모드가 많이 이용된다. 압전 단결정의 경우 특정 면방향으로 가공했을 때 $\mathrm{d}_{32}$ 모드의 압전상수가 $\mathrm{d}_{31}$ 모드 에 비해 월등히 높은 경우가 있는데, 앞서 소개한 압전 단결정을 활용한 $\mathrm{ME}$ 복합체에서는 $\mathrm{d}_{32}$ 모드를 사용한 경 우가 많았다. 압전 단결정의 $\mathrm{d}_{32}$ 모드를 $\mathrm{ME}$ 복합체에 사 용할 시 $\mathrm{d}_{31}$ 모드 진동에 의한 공진주파수와 $\mathrm{d}_{32}$ 모드 진동 에 의한 공진주파수의 차이가 크지 않다. 비교적 근거리
에 위치한 두 공진 주파수는 하베스팅 응용에 있어서는 구동 대역폭을 넓히는 장점을 갖지만, 두 공진 간의 상 호작용으로 인해 자기장 감지 민감도에 영향을 줄 수 있 다. 이러한 한계점을 해결하기 위해 2019년 영남대 연구 팀은 전단모드인 $\mathrm{d}_{36}$ 모드 PMN-PZT 단결정을 Metglas 와 결합하여 넓은 주파수 대역폭에서 단일 공명모드를 갖는 2-2 결합 $\mathrm{ME}$ 복합체를 제작하였다. ${ }^{19)} \mathrm{d}_{36}$ 모드는 전단 $\mathrm{d}_{15}$ 모드처럼 높은 압전상수 및 전기기계 결합계수 를 가지며 $\mathrm{d}_{31}$ 모드처럼 분극이 쉽게 형성되는 이점을 가 지는데, 그림13 (a)에서 볼 수 있듯이 $\mathrm{d}_{32}$ 모드 단결정의 자발분극 방향을 45 도 회전하여 모서리 방향으로 자발 분극이 형성되도록 제작되었다. PMN-PZT 단결정은 모드에 따른 $\mathrm{ME}$ 복합체의 특성을 비교하기 위해 각각 $\mathrm{d}_{31}$ 모드, $\mathrm{d}_{32}$ 모드, $\mathrm{d}_{36}$ 모드로 준비되었고, Metglas와 에 폭시로 접착되어 모드에 따른 $\mathrm{ME}$ 변환계수를 확인하였 다. 그림13 (b)처럼 각각 다른 모드의 $\mathrm{ME}$ 복합체를 주파 수에 따른 $\mathrm{ME}$ 변환계수로 비교하면, $\mathrm{d}_{31}$ 모드에 비해 $\mathrm{d}_{32}$ 모드의 공진 $\mathrm{ME}$ 변환계수는 높지만 공진이 둘로 나눠져 나타나게 된다. 반면 $\mathrm{d}_{36}$ 모드의 공진은 단일하게 나타 나며 $\mathrm{ME}$ 변환계수 값도 $\mathrm{d}_{32}$ 모드와 근사한 값을 가진다. $\mathrm{d}_{36}$ 모드의 공주파수는 시뮬레이션 결과 $(118 \mathrm{kHz})$ 와 근사 
하게 $103 \mathrm{kHz}$ 의 값을 가졌다. 이어서 $\mathrm{d}_{36}$ 모드 $\mathrm{ME}$ 복합 체의 공진 주파수 $(103 \mathrm{kHz})$ 와 비공진 주파수 $(1 \mathrm{kHz})$, 저 주파수 $(50 \mathrm{~Hz})$ 에서 가해주는 자기장의 방향을 [100]과 [011]로 달리하여 자기장 감지특성을 확인 하였다. 비공 진과 저주파수에서는 $2 \mathrm{nT}$, 공진주파수에서는 $2 \mathrm{pT}$ 의 민 감도를 가지는 것으로 확인되었다. 낮은 주파수에서는 민감도가 수 $\mathrm{nT}$ 에 그치며 $2 \mathrm{pT}$ 의 민감도를 가지기 위해 서는 동작 주파수가 높아지는 한계점이 있지만 $\mathrm{ME}$ 복합 체의 축의 길이 등을 조절하여 개선한다면 고성능 $\mathrm{ME}$ 자기센서로의 응용이 기대된다.

\section{4. 결론}

본고에서는 다양한 미세 자기장 감지기술, 자왜-압전 $\mathrm{ME}$ 복합체의 동작원리, $\mathrm{ME}$ 복합체를 활용한 자기장 감 지 연구동향에 대해 살펴보았다. $\mathrm{ME}$ 복합체는 기존 생 체자기장과 같은 초미세 자기장을 감지하는 SQUID에 비해 저비용 및 작은 부피로 구현이 가능하고 자기장 감 지 특성도 우수한 것으로 보고되고 있다. 현재까지 $\mathrm{ME}$ 자기센서의 특성을 향상시키기 위해 자왜재료, 압전재 료, 접착층, 신호처리 등의 분야에서 다양한 개선이 이 루어졌고, $1 \mathrm{pT}$ 이하 수준의 자기장을 감지하는 수준에 이르렀다. 하지만 아직까지 $1 \mathrm{kHz}$ 이하의 저주파 영역에 서는 수십 $\mathrm{pT}$ 수준의 자기장 감지가 가능하기에, 지속적 인 연구를 통해 $1 \mathrm{pT}$ 이하의 초미세 자기장 감지에 성공 해야 생체자기장 탐지에 응용될 수 있다. 또한 $\mathrm{ME}$ 복합 체를 활용한 생체자기장 탐지를 위해서는 $\mathrm{ME}$ 복합체에 서 발생하는 신호의 처리 및 증폭을 통한 신뢰적인 데이 터 확보가 필요한데, 아직까지 관련연구는 거의 이루어 지지 않았기에 보다 많은 관심이 필요하다. 향후 $\mathrm{ME}$ 복 합체의 저주파 자기장 감지특성 및 신호처리 기술이 발 달하면 배열화 및 시스템화를 통해 직접적으로 심장 또 는 뇌의 자기장을 감지하는 생체자기장 감지용 센서로 써 응용이 가능할 것으로 기대된다.

\section{REFERENCES}

1. S. O. Lee, C. K. Lee, I. Yun, N. S. Kim, and Y. J. Lee, "Study on Applicability of the Vehicle Detection Using a Coil Sensor," The Journal of The Korea Institute of Intelligent Transport Systems, 14(2), 14-23 (2015).

2. 손대락, "피드백형 플럭스게이트 마그네토미터 제작," 한국자기학회지, 22(2), 45-48 (2012).

3. 박용기, 이용호, 권혁찬, 김인선, 임현균, 김기웅, " 생체자기 (Biomagnetism) 의 측정 및 응용기술," 물 리학과 첨단기술, (2007).

4. Kim, G. H. (2009). 다강성 복합체 소재의 합성과 자기전기적 감수율 측정. Ceramist, $12(5), 21-24$.

5. J. Ryu, S. Y. Choe, J. U. Kim, G. H. Kim, and D. Y. Jeong, "자기-전기 복합체를 이용한 에너지 하베스터 기술," Ceramist, 18(4), 38-47 (2015).

6. R. C. Kambale, D. Y. Jeong, and J. Ryu, “ Current status of magnetoelectric composite thin/thick films," Advances in Condensed Matter Physics, (2012).

7. J. Ryu, A. V. Carazo, K. Uchino, and H. E. Kim, "Magnetoelectric properties in piezoelectric and magnetostrictive laminate composites," Japanese Journal of Applied Physics, 40(8R), 4948 (2001).

8. 이경우, 소형종, 임실묵, 김원호, 김대연, "1-3형 압 전복합체를 이용한 광대역 수중 음향 트랜스듀서 개 발," 한국소음진동공학회논문집, $18(4), 424-431$ (2008).

9. J. Ryu, S. Priya, K. Uchino, and H. E. Kim, "Magnetoelectric effect in composites of magnetostrictive and piezoelectric materials," Journal of electroceramics, 8(2), 107-119, (2002).

10. S. Dong, J. Zhai, J. Li, and D. Viehland, "Near-ideal magnetoelectricity in highpermeability magnetostrictive/piezofiber laminates with a (2-1) connectivity," Applied Physics Letters, 89(25), 252904 (2006).

11. J. Gao, L. Shen, Y. Wang, D. Gray, J. Li, and D. Viehland, "Enhanced sensitivity to direct current magnetic field changes in Metglas/ $\mathrm{Pb}\left(\mathrm{Mg}_{1 / 3} \mathrm{Nb}_{2 / 3}\right) \mathrm{O}_{3}-\mathrm{PbTiO}_{3}$ laminates," Journal of Applied Physics, 109(7), 074507 (2011). 


\section{특 집 표 황건태, 송현석, 장종문, 류정호, 윤운하}

12. Y. Liu, J. Jiao, J. Ma, B. Ren, L. Li, X. Zhao, and L. Shi, "Frequency conversion in magnetoelectric composites for quasi-static magnetic field detection," Applied Physics Letters, 103(21), 212902 (2013).

13. J. Zhang, P. Li, Y. Wen, W. He, J. Yang, M. Li, and W. Li, "High-sensitivity laminated magnetoelectric sensors without bias in composite of positive/negative giant magnetostrictive materials and piezoelectric single crystals," Journal of Applied Physics, 115(17), 17E517 (2014).

14. Z. Chu, H. Shi, W. Shi, G. Liu, J. Wu, J. Yang, and S. Dong, "Enhanced resonance magnetoelectric coupling in (1-1) connectivity composites," Advanced Materials, 29(19), 1606022 (2017).

15. V. Annapureddy, H. Palneedi, W. H. Yoon, D. S. Park, J. J. Choi, B. D. Hahn, and J. Ryu, “ A pT $/ \sqrt{ } \mathrm{Hz}$ sensitivity ac magnetic field sensor based on magnetoelectric composites using low-loss piezoelectric single crystals," Sensors and Actuators A: Physical, 260, 206-211. (2017)
16. G. T. Hwang, H. Palneedi, B. M. Jung, S. J. Kwon, M. Peddigari, Y. Min, and J. H. Choi, "Enhancement of magnetoelectric conversion achieved by optimization of interfacial adhesion layer in laminate composites," ACS applied materials \&interfaces, 10(38), 3232332330 (2018).

17. Z. Chu, W. Shi, H. Shi, Q. Chen, L. Wang, M. J. PourhosseiniAsl, and S. Dong, "A 1D Magnetoelectric Sensor Array for Magnetic Sketching," Advanced Materials Technologies, 4(3), 1800484 (2019).

18. Z. Chu, Z. Yu, M. PourhosseiniAsl, C. Tu, and S. Dong, "Enhanced low-frequency magnetic field sensitivity in magnetoelectric composite with amplitude modulation method," Applied Physics Letters, 114(13), 132901 (2019).

19. S. Park, M. Peddigari, G. T. Hwang, W. H. Yoon, A. Kumar, and J. Ryu, "Faceshear 36-mode magnetoelectric composites with piezoelectric single crystal and Metglas laminate," Applied Physics Letters, 115(10), 102901 (2019). 


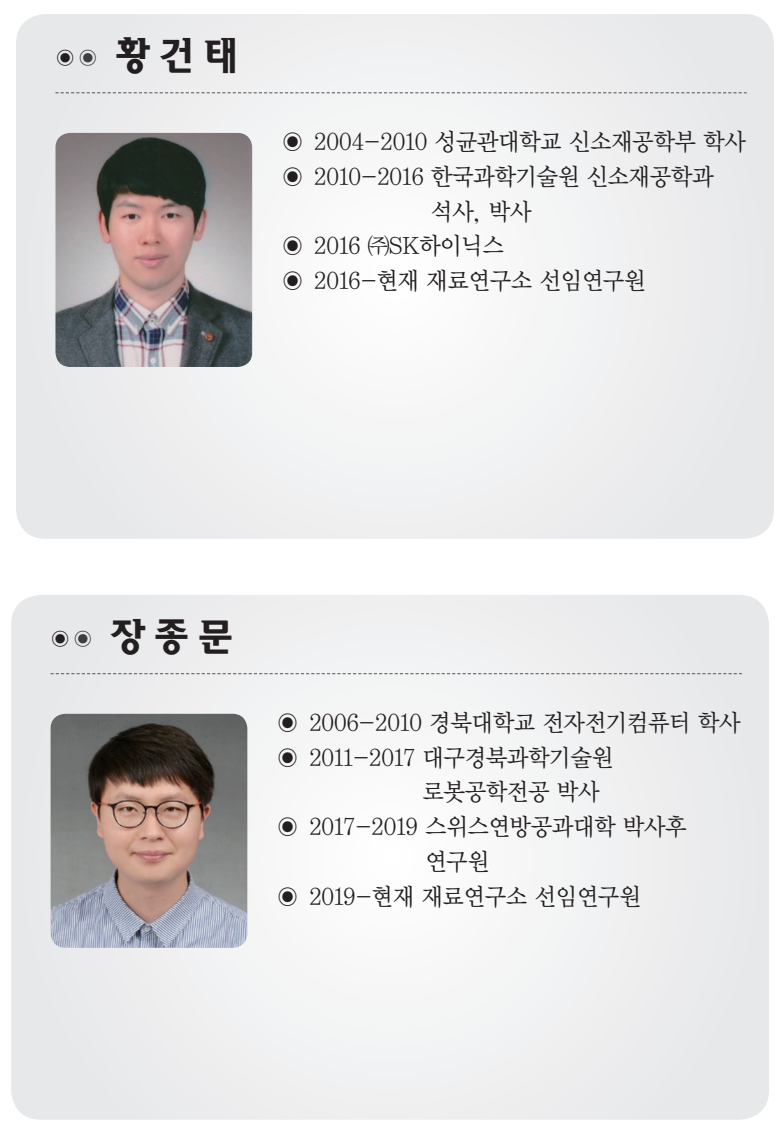

\section{․ㅇ윤 운 하}

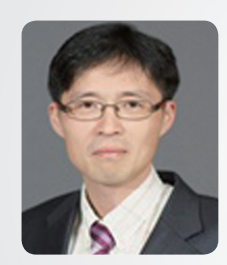

( 1985-1989 인하대학교 공학사, 응용물리학

- 1990-1992 인하대학교 공석사, 응용물리학

( 1997-2001 부경대학교 이학박사, 물리학

- 1992-1996 한국기계연구원 비파괴평가그룹 연구원

( 1997-2006 한국기계연구원 원자력사업단 미래기술연구부 선임연구원

( 2007-현재 한국기계연구원 부설 재료연구소 기능세라믹그룹 책임연구원

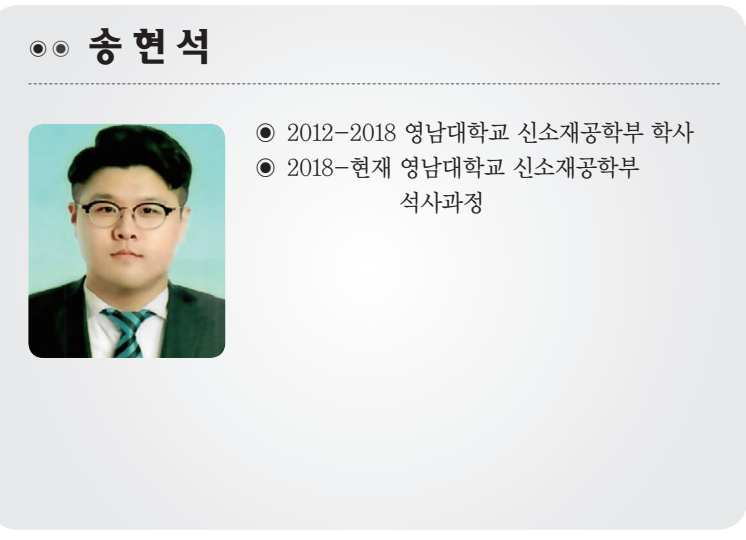

\section{••류정호}

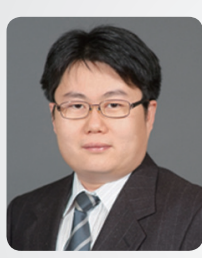

( 1992-1998, 영남대학교 무기재료공학과 학사, 석사

( 1998-2001, 서울대학교 재료공학부 박사

- 2000-2003, Pennsylvania State

University 방문연구원,

박사 후 연구원

- 2003-2006, 삼성전기 OS 사업부 책임연구원

- 2006-2018, 재료연구소 책임연구원

( 2018-현재 영남대학교 신소재공학부 교수 